\title{
Stumbling Blocks and Barriers to the Use of ICT in Schools: A Case Study of a Hungarian Town
}

\author{
András BUDA \\ University of Debrecen, Institute of Educational Studies and Cultural Management, Hungary \\ e-mail: buda.andras@arts.unideb.hu
}

Received: September 2019

\begin{abstract}
Most countries attempt to catch up with technological progress and digitise their educational environment, but still there are few teachers that integrate ICT in education adequately. Several factors may hinder this process, whose exploration is important because only after learning about these barriers can efficient counteractions be taken.

One of the goals of our surveys in 2009, 2013 and 2016 realised through own-produced, online questionnaires was to disclose the disadvantages of using ICT in school from the perspective of teachers and what these teachers needed to ensure progress, that is, a more frequent and more efficient use of ICT.

According to the altogether 1260 respondents, besides a basic lack of devices, Debrecen teachers' use of the new technologies is increasingly hindered by their fear of an attention gap exhibited by students and the related problems. This acts as a kind of cognitive barrier to using the technologies, even though teachers regard these new solutions with less and less animosity.
\end{abstract}

Keywords: ICT, teachers, educational ICT use, ICT integration, obstacles of ICT integration.

\section{Introduction}

The life of citizens of developed countries is dominated by technology in all areas. Those that cannot use the new devices and solutions properly have thinner chances of finding a well-paid job, and will find it more difficult to take care of their business or keep contact with others, to gain access to several products, services, information, etc. In the information society of the 21 st century especially the latter presents a great disadvantage, as today's primary resource is information, one of the bases of social differentiation. It is easy to see that the opportunities available to computer literates and illiterates differ significantly and only the former can participate successfully in society, in economic and civilian life.

The significance of ICT has been recognised in most European countries and it has been a key priority to integrate it in the countries' educational systems (Balanskat et al., 2006). Governments spend substantial funds on school ICT devices, but educational and 
training systems still do not make the most of the inherent possibilities. According to a comprehensive survey, $70 \%$ of educators in the European Union already realised and acknowledged the importance of digital support for teaching and learning at the beginning of the decade, but only $20-25 \%$ of the students have been taught by teachers who possessed ample digital proficiency to make this happen (European Commission 2013). Positive attitudes are mostly observed in connection to preparing the lessons, as teachers primarily use information and communication technologies for preparing and not in order to apply them in the lessons together with their students. According to the results of the $1^{\text {st }}$ and $2^{\text {nd }}$ 'European Survey of Schools: ICT in Education' (ESSIE) organised by the European Commission in 2011 and 2012 as well as in 2017 and 2018, respectively, the overwhelming majority of teachers (over 90\%) use ICT for preparation at every educational level. However, the number of teachers actually using digital technologies in over $25 \%$ of the lessons is far behind that figure despite the fact that there was significant progress made in between the two surveys. In the first case at levels ISCED 3 and ISCED 2 the proportion of teachers using digital technologies in over $25 \%$ of the lessons rose to $65 \%$ and $58 \%$, respectively, at the time of the second survey. Improvement is even greater at ISCED 1 level, where the percentage rose from $29 \%$ to $71 \%$. Unfortunately the results in Hungary did not approximate the European average in any subgroups examined. What is more, in the second survey with the exception of the ISCED 1 group the lowest values came from Hungary: as opposed to the results of the top countries, which were all around $90 \%$, here the highest value was $42 \%$ (at ISCED 3 ). Taking into account the results of the other two groups examined we may establish that only over two thirds of Hungarian teachers use ICT devices in over $25 \%$ of the lessons.

The conclusion based on the data is in concord with the observations of several authors (cf. Baggott et al., 2003; Orlando, 2014, Rončević et al., 2017): positive attitudes notwithstanding it is only slowly and reluctantly that teachers change their teaching practices. The case in reality is that "teachers tend to "assimilate" use of ICT into existing practices rather than to "accommodate" it in terms of changing their subject content, goals and pedagogies' (Hennessy, et al. 2005, 30). Therefore, it seems obvious that if we wish to encourage teachers to integrate the technologies in their teaching processes, the different obstacles must be removed. This is why it is important to conduct an investigation into the stumbling blocks hindering teachers.

\section{Barriers to the Use of ICT on the Basis of Earlier Surveys}

The integration of digital technologies in the teaching process may be hindered by several factors, which were already researched in the early 1990s. A basic problem in this period was an inadequate supply of assets, as few computers were available to teachers in schools and homes. Several teachers complained about having no time to successfully integrate the technologies in the curriculum, and required support personnel in the classrooms to supervise the use of computers and assist those students (!) that cannot (properly) operate the computers (Winnans and Brown, 1992). Of factors most hindering the use of computers in schools - apart from the lack of assets - Hadley and 
Sheingold highlighted the lack of teachers' experience in using the new technologies and mentioned that local support for teachers using the technologies was lacking (Hadley and Sheingold, 1993). In the schools examined by Rosen and Weil, however, teachers had access to computers, still they did not use them. They found the major cause to be teachers' technophobia. The teachers surveyed were most concerned about the malfunctioning of computers in the classrooms, and their dismissive attitude towards learning through computers was a source of further problems (Rosen and Weil, 1995). For the teachers examined by Cox et al. (1999), the biggest problem was the various difficulties met when using ICT, but the methodological and pedagogical values of ICT were also shown to be significant influencing factors. Virtually assessing the results of the 1990s, Ertmer delegates the barriers to change into two categories: primary and secondary barriers (Ertmer, 1999). The first category includes reasons independent of the teachers, in addition to the lack of computers and software, the insufficient technological and administrative support, as well as the little time period allotted to planning the curriculum, even though the latter element is contestable. According to Ertmer, the school as an institution provides teachers with little time to learn about ICT solutions and to practice new tricks. Secondary barriers, however, are evidently connected to teachers and include teachers' conservative views on teaching and new technologies as well as their lack of readiness to change.

Using a different categorisation, Mumtaz delegated barriers to three groups, differentiating between economic, school-level and teacher-level barriers (Mumtaz, 2000). Of these, Mumtaz states, it is clearly the teacher-level barriers that have the greatest impact, which primarily lie not in the proficiency in using the given technology but teachers' attitudes, their pedagogical convictions and dedication. In her opinion, ICT solutions are most valuable for such educators as are motivated and strongly committed to students' learning and their own professional development. These teachers can more easily integrate digital solutions in their teaching practices and are ready to entirely restructure their practices if needed.

In the first years of the new millennium, too, many examined the different barriers to integrating ICT in education successfully. Similarly to the former studies, some researchers listed their findings and highlighted the most significant ones. For instance, according to Bingimlas (2009), the primary barriers to a successful integration of ICT are: a distrust of the technologies, the inadequacy of teachers' digital competencies as well as a lack of access to resources. Law et al. (2008a) established that the most basic factor hindering ICT use is the lack of professional development on the part of the educators. In Player-Koro's observation, the most significant conditions are related to teachers, namely their self-efficacy and attitudes. In connection to these, she calls attention to the fact that the impact works two ways: it is not only these two factors that affect teachers' ICT use, but the use of ICT can also influence them (Player-Koro, 2012). Several observations verify that early successes may reinforce or even induce a positive attitude, while bad experiences may initiate a downward spiral in connection to the use of ICT in lessons.

Kafyulilo et al. (2016) also examined the factors influencing teachers' use of technology. Their study pinpoints the school management's encouraging or hindering attitudes 
as the most critical of the barriers found. Beyond these it is important to emphasise that in their list there also appeared problems (e.g. large classrooms, problems of power supply) that raised attention to the fact that the result of similar surveys is strongly influenced by the location of the study (Kafyulilo et al. conducted their research in Tanzania). This is supported by Alshmrany and Wilkinson (2017), too, who assessed factors hindering ICT use in Saudi Arabian primary schools. Their data showed that the application of digital solutions is substantially affected by cultural and social customs and norms, which have a significant impact in addition to computer literacy and a trust in technology.

In another type of integration surveys researchers gathered factors hindering the use of ICT in schools by creating different categories of such factors. Some scholars delegated barriers to two groups, as did Pine-Thomas (2017), who, similarly to Ertmer (1999), used the terminology of first- and second-order barriers, whereas others (e.g. Tedla, 2012, Johnson et al., 2016) applied the terms external and internal barriers. Pelgrum (2001) called his groups material and non-material barriers, assigning to the former the inadequate number of computers and software, and to the latter the low level of teachers' ICT proficiency, methodological difficulties, and the lack of teachers' preparation time.

Zhao et al. (2002) distinguished barriers to ICT use along three factors: the innovator, the innovation, and the context. The teacher (the innovator) is the most important factor, as their technological proficiency and pedagogical compatibility provide the fundaments of the process. If this condition is given, then the success of using new devices and solutions depends upon their intimate connection to the given school's culture and practice, and upon the resources and support available. Of these especially important are those that are directly controlled by the innovator. Finally, the third area, which has an intense impact on the success of technological innovations in school, is the context (school environment) in which the innovations take place. The scholars emphasised three elements in school environment (Zhao et al. 2002, 502):

1) Human infrastructure.

2) Technological infrastructure.

3) Social support.

Balanskat et al. (2006) also established three categories for barriers, namely microlevel (teacher), mid-level (school) and system-level barriers. Teacher-level barriers include weak motivation, a distrust of new technologies and low-level digital proficiency. School-level barriers include the availability of assets, the substandard quality of these, lacking digital contents, educational software. Finally, system-level barriers include an inflexible regulatory environment and the lack of centralised support.

In their comprehensive work, Hew and Brush (2007) summarise the findings of 48 studies in which the authors present their various empirical investigations. In the works examined they find altogether 123 barriers that may hinder the use of ICT for educational purposes. These factors are then organised into six categories and their frequency is investigated, too. They find that the most frequent problem is related to matters of resources (40\%), but teachers' knowledge and skills is another hindering factor (23\%). The importance of these two elements is well exemplified by the fact that the barriers in the other four categories yield less than one third of the barriers disclosed: institution (14\%), attitudes and beliefs (13\%), assessment (5\%) and subject culture (2\%). 


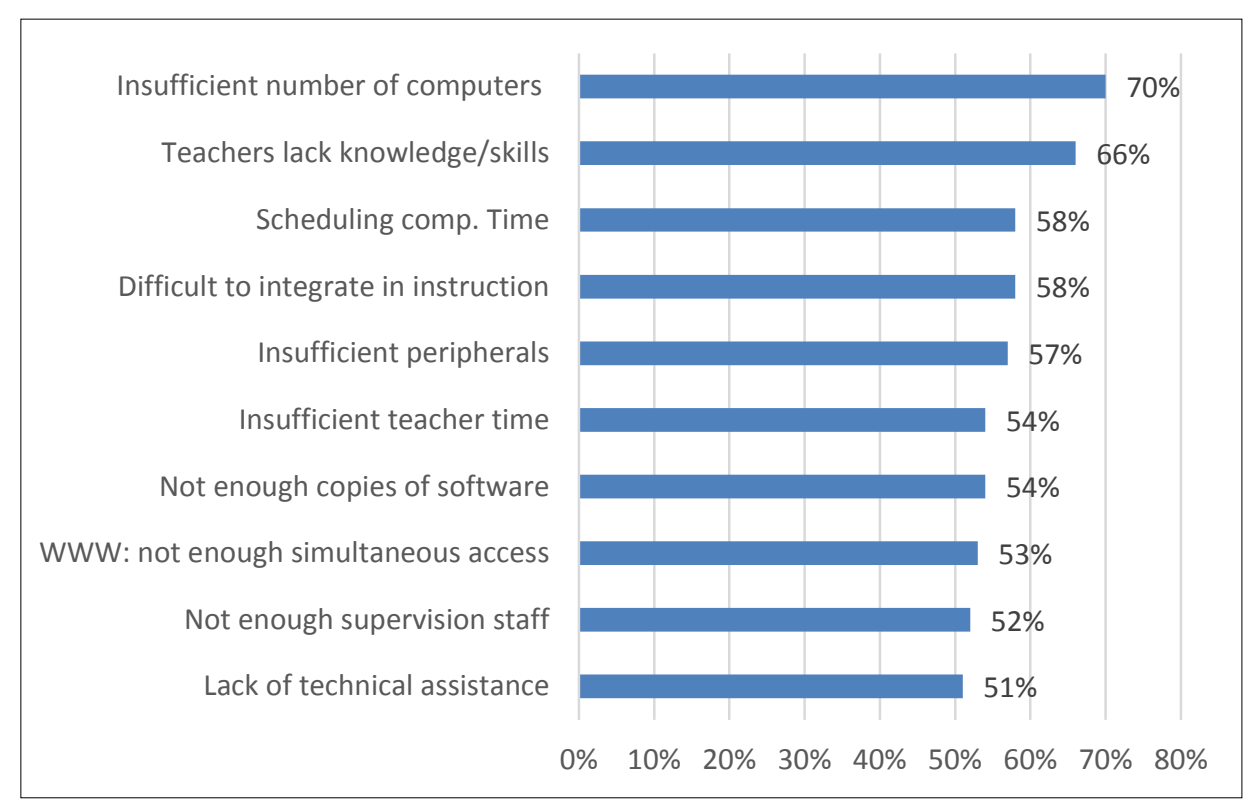

Fig. 1. Barriers to the use of ICT according to the findings of SITES-M1 surveys. (Own diagram based on Pelgrum 2001, 173)

Naturally, international surveys on school ICT use and the barriers thereto have also been launched. IEA (The International Association for the Evaluation of Educational Achievement) started its research series Second Information Technology in Education Study (SITES) ${ }^{1}$ in the late 1990s. Primarily they wished to know the impact of ICT on learning and teaching in schools in different countries. In the research related to the first module (SITES-M1) they investigated the barriers to ICT use, too. They compiled a list of 38 items, and the respondent head teachers and technological personnel chose the appropriate replies in relation to barriers to the institution's teaching goals. On the basis of the responses, the researchers highlighted 10 hindering factors of the many, which were marked by over half of the respondents.

The list includes material and non-material problems, but it is hardly surprising that the barrier most often mentioned is the insufficient number of computers.

The findings of the study in the third module titled SITES 2006 give evidence of significant change. Conspicuously here no replies have been marked by more than half of the respondents.

In SITES-M1 the insufficient number of computers and the lack of teachers' knowledge and skills were highlighted, but by the time of the third module, the intensity of the two barriers had been mitigated by almost $40 \%$. There, however, appeared other problems such as the obsolete condition of devices and the insufficient bandwidth, appearing in the top ten problems. So according to respondents, in this area there is need for a change in quality rather than quantity.

\footnotetext{
1 https://www.iea.nl/studies/iea/sites
} 


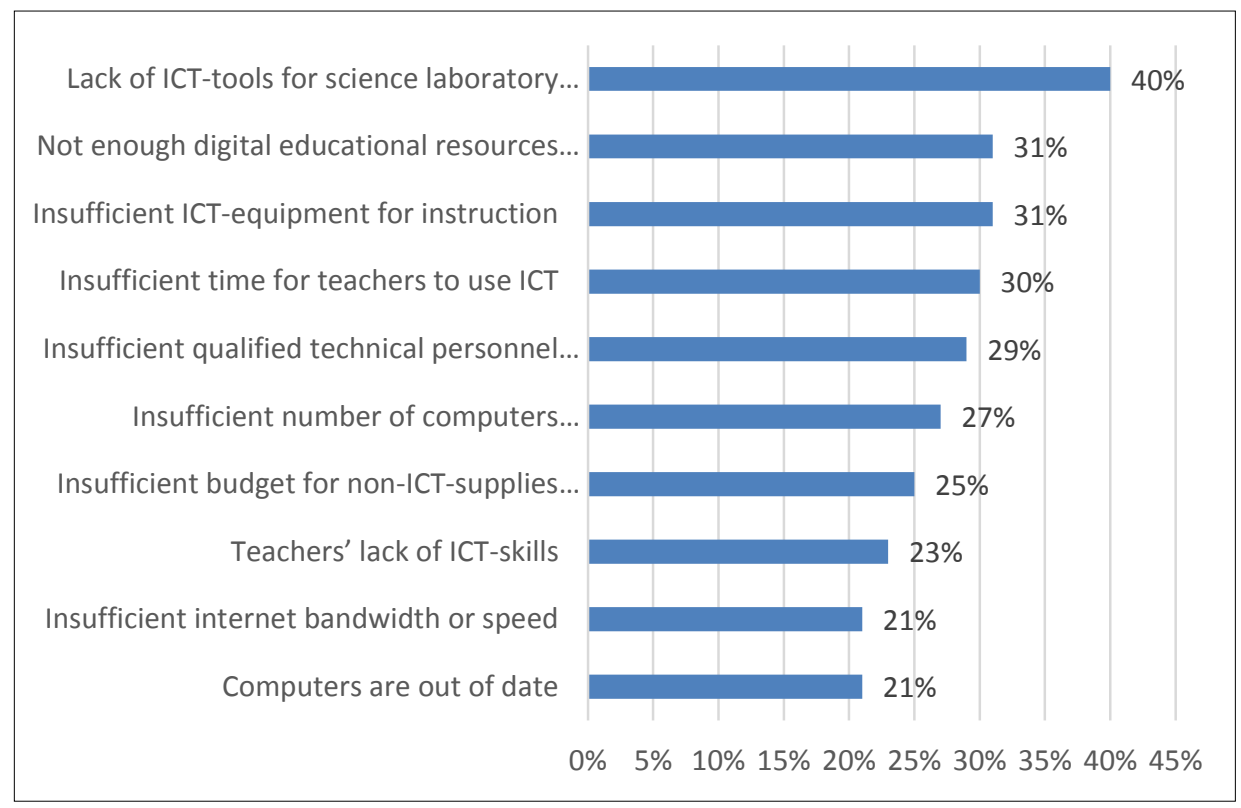

Fig. 2. Barriers to the use of ICT according to the findings of SITES-M3 surveys.

(Own diagram based on Law et al., 2008b)

When implementing the third module the researchers asked teachers, too, to mark any barriers of the 12 listed which they encounter when applying digital technologies in the lessons. When processing the responses the 12 barriers were categorised thus:

- 'School related:

- ICT is not considered useful in my school.

- My school does not have the required ICT-infrastructure.

- My school lacks digital learning resources.

- I do not have the flexibility to make my own decisions when planning lessons with ICT.

○ I do not have access to ICT outside of the school.

- Teacher related:

○ Lack of ICT-related skills.

○ Lack of ICT-related pedagogical skills.

- Insufficient confidence to try new approaches alone.

- Lack of time to develop and implement ICT-using activities.

○ Unable to identify which ICT tools will be useful.

- Student related:

- Students do not possess the required ICT-skills.

- Students do not have access to the required ICT-related tools outside of the school premises' (Law et al., 2008b, 199). 
One of the key findings of the SITES 2006 research is also connected to this problem: 'The most serious obstacles to ICT utilization in the classroom are school-related rather than student-related. The SITES data showed that the surveyed teachers identified lack of support as the most significant obstacle' (Law et al., 2008b, 276).

Another international research series even more comprehensively detailing the barriers of school ICT use is called ESSIE (European Survey of Schools: ICT in Education), of which two surveys have been organised. 31 countries (EU27, Croatia, Iceland, Norway and Turkey) participated in the first study realised in 2011. The researchers listed 20 possible barriers, with the intention to learn about the opinions of the people managing school work, that is, school principals (head teachers). On the basis of the responses, the 20 possible barriers were assigned to three factors through factor analysis:

1. 'Equipment' - inadequate, outdated assets, low bandwidth.

2. 'Pedagogy' - unprepared teachers, the lack of technological and pedagogical support; the lack of appropriate digital contents and good practices.

3. 'Goal' - as the advantages of ICT use are not readily evident, parents and teachers oppose its application, so the use of ICT is not a goal of the institution. (European Commission 2013).

In 2018 again 31 countries (EU28, Norway, Iceland and Turkey) were involved in the second ESSIE survey. At the time 22 barriers were outlined by the research, which were finally arranged along three groups:

1. Equipment-related obstacles: insufficient number of devices and internet connections, outdated computers needing repair, low bandwidth.

2. Pedagogy-related obstacles: the lack of teachers' appropriate skills; inadequate technological and pedagogical support; the lack of appropriate digital contents, especially in the given nation's language; ICT's integration in the curriculum; lacking pedagogical models for applying ICT.

3. Attitude-related obstacles: the resistance of parents and teachers; the lack of teachers' interest; the advantages of using of ICT in education are not readily evident; so the use of ICT in teaching and learning is not a goal in schools. (European Commission, 2019).

The studies presented also prove that research into factors hindering the use of ICT in schools is an important step towards improving the standard of education and learning. Well-established decisions can only be made after learning about the problems. At the same time researches listing and grouping the barriers eclipse some information, such as the fact that the total lack of computers, their insufficient number or their outdated condition are equally listed as economic problems, even though these differ substantially from the perspective of organising the practical activities. Groupings are, however, useful as the well-chosen names of categories may direct attention to the problems, promoting faster solutions. The recognition of hindering factors may help teachers, too, to overcome these barriers and become successful users of the technologies. We wish to have a similar impact with the findings of our own research. 


\section{Goals, Methods and Specifics of the Surveys}

We organised our surveys in the second largest city of Hungary, Debrecen starting with 2009. During our research we collected data related to different interfaces between ICT and teachers as well as their work. We set several goals: on the one hand, to disclose the characteristics of teachers' knowledge of, attitudes toward and opinions about digital technology; on the other hand, to map the specifics of private and work-related computer and Internet use.

We contacted teachers of primary and secondary schools of the city on three occasions with our continuously developing and changing questionnaire. This was supported by the municipality's Department of Education and the head teachers of the schools, and thus our questionnaire was received by all potentially competent persons. We organised the first survey in 2009 with an own-designed online questionnaire edited in the Evasys system. In this year we received 287 qualifiable responses, from $11.2 \%$ of the total number of teachers in the schools in the given year. In 2013 we repeated the survey with another online questionnaire, then 429 people responded to our questions $(14.5 \%$ of all the teachers), while in the third survey realised in winter 2016 we registered 544 respondents (18.4\% of all the teachers). As a result of the repeated investigations, we can go beyond a momentary situation report and can draw an arc of development - albeit a limited one -, showing changes and tendencies in the use of ICT. Drawing averages of the findings is somewhat hindered by the fact that respondents were not and could not have been completely identical, as teaching staffs in schools changed due to the exit of retired colleagues and career changers and the entry of career starters. Some institutions were terminated, some others were fused, new branches and trainings were introduced, the curriculum changed as well as the structure of some subjects (KIRSTAT, Fazekas 2016). Another important factor is that owing to the change of students' populations not examined in our research - the informal teaching environment or climate was transformed significantly in several institutions (Pusztai 2015, Szemerszki 2016), which also had an impact on teaching methods used. Apart from these factors, nonetheless, we believe that our findings have great precision in reflecting reality. This is supported by the fact that the breakdown of workplace types of the respondents (primary schools $60.7 \%$, secondary schools $-39.3 \%$ ) is practically identical to the national figures, as in the past years on the basis of KSH's (the Central Statistics Office) data (KSH 2017) an average of $61.3 \%$ of teachers worked in primary educational institutions in Hungary. Regarding the sex of the respondents ( $77 \%$ women, $23 \%$ men) the difference from national data is only slight, even though in our surveys men are somewhat overrepresented, as based on Hungarian data the percentage of women teachers since the early 2000 s has not deviated from $82 \%$ too significantly (Varga 2015), but in our surveys the proportion of women respondents was slightly lower.

The point of departure when developing the questionnaires of the subsequent surveys was the questionnaire from the 2009 research, but due to the changes of the digital world we continuously updated it. Newer questions appeared, e.g. on more up-to-date devices and methods, and we enriched our earlier work with new goals and perspectives. Table 1 presents the development of the questionnaire. 
Table 1

Changes in the blocks of questions in the questionnaire

\begin{tabular}{|c|c|c|c|}
\hline Blocks & 2009 & 2013 & 2016 \\
\hline Questions on background & $\mathrm{X}$ & $\mathrm{X}$ & $\mathrm{X}$ \\
\hline Questions on attitudes & $\mathrm{X}$ & $\mathrm{Xv}$ & $\mathrm{Xv}$ \\
\hline Advantages and disadvantages of ICT & $\mathrm{X}$ & $\mathrm{X}$ & $\mathrm{X}$ \\
\hline $\begin{array}{l}\text { Questions on teaching (teaching tools and materials used in } \\
\text { preparation and in lessons) }\end{array}$ & $\mathrm{X}$ & $\mathrm{Xv}$ & $\mathrm{X}$ \\
\hline Awareness of websites also used in education & & & $\mathrm{X}$ \\
\hline Questions related to the use of computers & $\mathrm{X}$ & $\mathrm{X}$ & $\mathrm{X}$ \\
\hline Questions on and examples of digital illustration & & $\mathrm{X}$ & $\mathrm{X}$ \\
\hline Questions on Internet use & $\mathrm{X}$ & $\mathrm{X}$ & $\mathrm{X}$ \\
\hline Elements lacking but necessary for the use of ICT & & $\mathrm{X}$ & $\mathrm{X}$ \\
\hline Problems related to students & $\mathrm{X}$ & $\mathrm{X}$ & $\mathrm{X}$ \\
\hline Necessity of individual ICT devices & $\mathrm{X}$ & $\mathrm{X}$ & $\mathrm{X}$ \\
\hline Interactive boards and their use & $\mathrm{X}$ & $\mathrm{X}$ & $\mathrm{X}$ \\
\hline Questions on further training & & $\mathrm{X}$ & $\mathrm{X}$ \\
\hline Questions on social media websites & & $\mathrm{X}$ & $\mathrm{X}$ \\
\hline
\end{tabular}

$\mathrm{X}$ signifies the presence of a block, while Xv its change - generally expansion.

The table attests another reason for enriching the questionnaire: in the 2013 and 2016 surveys we also strove to ensure that teachers - alongside articulating their replies - also learn new ideas and methodological tricks. Thus it was not only the respondents that supplied data and information to us by filling in the questionnaires but they, too, received help with carrying on with their work.

Of the rich database created by making use of the questionnaires we heretofore present the factors hindering the digitisation of schools and teaching as well as examine our respondents' views on opportunities for developing the use of ICT in school.

\section{The Drawbacks of Using ICT - According to Teachers}

Our respondents received the following questions in all three surveys: 'What do you think are the disadvantages of using informatics devices in education?' Of the altogether 1260 teachers completing the questionnaire, $866(69 \%)$ replied to this question, providing 1408 replies in total. Approximately one fifth (163 people) of the respondents, however, replied that the use of IT equipment in schools had no disadvantages at all in their view! (e.g. 'I cannot mention any, I think there are only advantages. '; 'I don't think it has any drawbacks. It is extremely important in our subject. If you don't have these in the lesson, you can feel their absence.' ${ }^{2}$ ). Altogether a little over half of the respondents $(57 \%)$ named any disadvantages. The responses were brief and terse, the teachers marked mostly one or possibly two factors and there were few replies with full

\footnotetext{
${ }^{2}$ Passages in italics are directly quoted from the responses.
} 
sentences. A substantial amount of these diversifies the responses of teachers denying the existence of disadvantages, as 56 teachers think problems could only be eliminated if some condition were given. Most people call attention to the necessity of a balance: 'If we find the right proportions of the convention of reading and taking notes and using ICT, there are no disadvantages.' Others emphasised the importance of method - 'There are disadvantages only when teachers apply these in the wrong way. E.g.: watching films in lessons without any didactic goals. Teaching without taking records, etc.', - and the necessary presence of a teacher: 'I cannot see any disadvantages if it is used cleverly, that is, not instead of a teacher.'

The responses naming real disadvantages have been categorised after content analysis, and the groups created were assigned 'telling' titles. ${ }^{3}$

The narrowing down of oral communication, the deterioration of writing $(152-10,8 \%)$

Among the responses appeared a great deal of general aspects hindering the effect of education, which also generate professional and social debates in relation to IT devices. One such aspect is the impact on communication. Several teachers report negative changes in oral communication: 'the magic of live speech might be relegated to the background. Personal verbal communication might be impoverished.' As a result many find that students 'cannot articulate 5-10 sentences independently.' They are characterised by 'the deterioration of eloquent articulation and expression, as well as a substandard manner of speech and slang (chat, text messages). ' Others find a setback in written communication: 'Grammatically correct writing in many cases becomes unjustified, as the computer automatically indicates incorrectly typed words. Beyond that most students have a terrible written hand, since they do not practice the handwritten form.' Many teachers have the experience that for the students of the $21^{\text {st }}$ century 'the value of traditional writing is lost, they have only one solution to everything, the Internet, and if there is no connection, they know of no other solutions (no libraries, no books). (And they find this a really good reason not to finish an assignment.)"

\section{Distraction $(139-9,9 \%)$}

Digital technologies make possible much richer and spectacular illustration than before, but 'mostly the flashy presentations just distract students from the point, and you have to find the way to make them focused on the teaching material.' Moreover, it is not only the visual stimulation that matters here, but the devices themselves have a similar effect: 'The many devices available to the pupils can be used in many ways, and there is a strong temptation to rush through and finish their mandatory assignment in a slipshod manner and then log on to the NET.'

${ }^{3}$ The values in parentheses following the category names signify the number of barriers belonging in the given category, and the percentages signify the proportion of replies belonging in the given category. 
Other responses to points in our questionnaire show that teachers feel remarkably overburdened. Taking this into account it is hardly surprising that one of the most frequently cited negative aspects has to do with time. In connection to this, our respondents find two different problems. One is the ever increasing time needed to prepare for the educational activity: 'preparation for the lessons takes up much more time and with the currently assigned mandatory number of lessons it is very difficult or impossible.' The other is the lacking equipment in rooms, including time-consuming access: 'It takes a lot of time and is physically taxing to move the computers and projectors to the venue of the lesson.' If somebody already has access to the equipment, then there could be a problem with assembling these devices, which again takes up a lot of time: 'in many cases setting up the technology takes 10-15 minutes away from the lesson. This is a luxury I can't afford.' In a nutshell, 'acquiring the devices takes time away from the break period, their setting up takes time away from the lesson. ' Some teachers also complain that the use of digital technologies in the lessons 'increases the time needed to process the teaching material instead of decreasing it, as weaker students must also be explained in the conventional way what they had been shown.'

Financing problems $(110-7,8 \%)$

Some of the time-related problems already covertly hinted at one of the basic symptom of economic problems: 'the rooms are not properly equipped: there is no computer, projector, screen, internet access or interactive board.' Many, however, interpreted the question more broadly and treated assets purchases as only one element of the problem. It is not enough to purchase the equipment, the maintenance of the purchased technology also results in considerable costs: 'after the attrition of devices there is no possibility of replacement or repair,' 'continuous operability of existing devices is not secured (due to the lack of funds we have to wait half a year for a bulb in the projector.)' Several institutions attempt to solve the problem by allowing the students to use their own devices for educational purposes. This, however, is not a solution in every school: 'the general use of mobiles and tablets is impossible, because some of the students do not have the appropriate devices, or internet access, and the school wifi network cannot serve all these demands.' Another cost-increasing factor in schools is the power bill and some respondents complained about 'the owner of the school not paying for the service in a timely manner and there was no internet connection available, even though the activity involving individual and controlled search for information necessitated it.'

There is another area of financial problems that many teachers brought up, the insufficient access to digital contents: 'there is a lack of electronic documents (DVDs, audiobooks, CD-ROMs, music CDs).' 'Most computer programmes and professional databases are unaffordable and/or schools do not spend on these. I don't want to use them illegally.' 
Technological problems $(101-7,2 \%)$

Several of our respondents mentioned the disadvantage of insecurely operating technological equipment and its potential malfunctions, as well as the unreliability of a network connection. Any of these can easily turn the preset lesson plan on its head, thus teachers must always prepare alternative solutions, too: 'Technological malfunctions (faulty computers, projectors or active boards), and in the case of lessons with online materials, the lesson plan fails when the internet connection is inactive, so you always need a plan B without the need for any technological devices.'

\section{Overdigitisation $(94-6,7 \%)$}

Many of the teachers completing the questionnaire fear that elements of teaching based on digital technology 'may overwhelm the lesson at the expense of conventional forms of teaching, which also have their rightful place in education. One has to find a healthy balance between the use of old methods and new ones.' If this should fail, 'the students only pay attention to the ICT devices working in their stead. For instance, in online exercises you have the solution a click away.' Of course, the teacher can be affected by modern technologies in a negative way, 'they can easily throw out the baby with the bathwater, become too comfortable, and not teach but only project things on the screen.' 'It is also possible that some teachers do not feel comfortable at all in this position: 'the active part of the lesson's 45 minutes is taken up by the use of digital devices, and as a teacher I don't have any time left for summarising and integrating the image material shown in the modules.' There are some who, shifting the responsibility, propound a rather extreme opinion: 'A one-sided, forced education based on the computer is the most harmful process that has ever been invented in the history of teaching.'

Books and reading is pushed to the background $(88-6,3 \%)$

In addition to ideas about the narrowing down and devolution of oral communication and grammar use as well as a declining handwritten form, the responses show barriers the effects of which go beyond the scope of the school. One of these is the background role of reading and books. Such an impact of digital technology is only mentioned by teachers in connection to the students: 'they don't have any patience to read longer texts', and there were respondents who offered reasons for their ideas: 'they go off books, the printed text is not so spectacular, and so it becomes boring for them.' As a result of the process, 'the use of books, albums and encyclopaedias is slowly forgotten.' 
Students forget how to think $(88-6,3 \%)$

In general, the respondents marked the barrier of the devolution of thinking processes in the same proportion as they did the devolution of reading. Some connected the two areas: 'imagistic thinking comes to the foreground at the expense of creative thinking developed by reading which encourages the use of the imagination.' The individual completion of tasks, the production of own answers to questions needs work and time, but according to many, digital devices 'get students out of the habit of finding solutions to problems and develop an addiction to a mindset looking for "ready-made answers without any effort'.' 'Teachers primarily attribute this negative impact to the World Wide Web: 'students can easily delude themselves that they can solve anything with the help of the internet, and it comes as a disappointment when they find out this is not true.'

According to some respondents the teachers themselves encourage this trend: "presentations make the lessons rigid, the students are groomed to think through key words and fragments of information instead of trains of thought.'

\section{Impersonal aspect $(72-5,1 \%)$}

Digital technologies have reshaped the manner and intensity of communication and keeping contact, so they have an impact on socialisation processes, too. The consequences are already seen in school: 'students' working away at their own computers can hinder the development of cooperation and social relationships.' Many think that the new devices make teaching more impersonal: 'I am an old-school teacher (which is not a problem of course), and I think that computers are "machines". They produce and promote alien and alienating effects (it is not the person but the computer that becomes important, instead of humanity they value knowledge, instead of the irreplaceable individual only advancement). I think a book is still more human, because you can smell it. The replies also included some fears that had been present in the public consciousness since the appearance of computers: 'They can annihilate the EDUCATOR. Who will the children remember? The software? The lady who operated the machine?'

Health impact $(47-3,3 \%)$

The barriers to using IT devices in education included the harm to health, which may appear in several forms. However, only one of these, the deterioration of sight, can be directly connected to schools: 'the projector's light harms students' eyes, it has a negative impact on their health.' Other similar medical problems marked by our respondents, however, are not closely tied to the educational institutions, since only individual long-term sessions may lead to the development of such, but in schools these are not realised. Such health risks include sitting in a permanently static position, which can 
result in 'deleterious bodily deformations (health problems with the hands and wrists, the spine, etc.) 'Along with physical deformations there could be psychosomatic consequences: 'Attractive, exciting activities can enslave the children; their dependence on games, chat and facebook can lead to a harmful addiction.'

The types of factors that hindered the use of ICT according to teachers changed throughout the period under review.

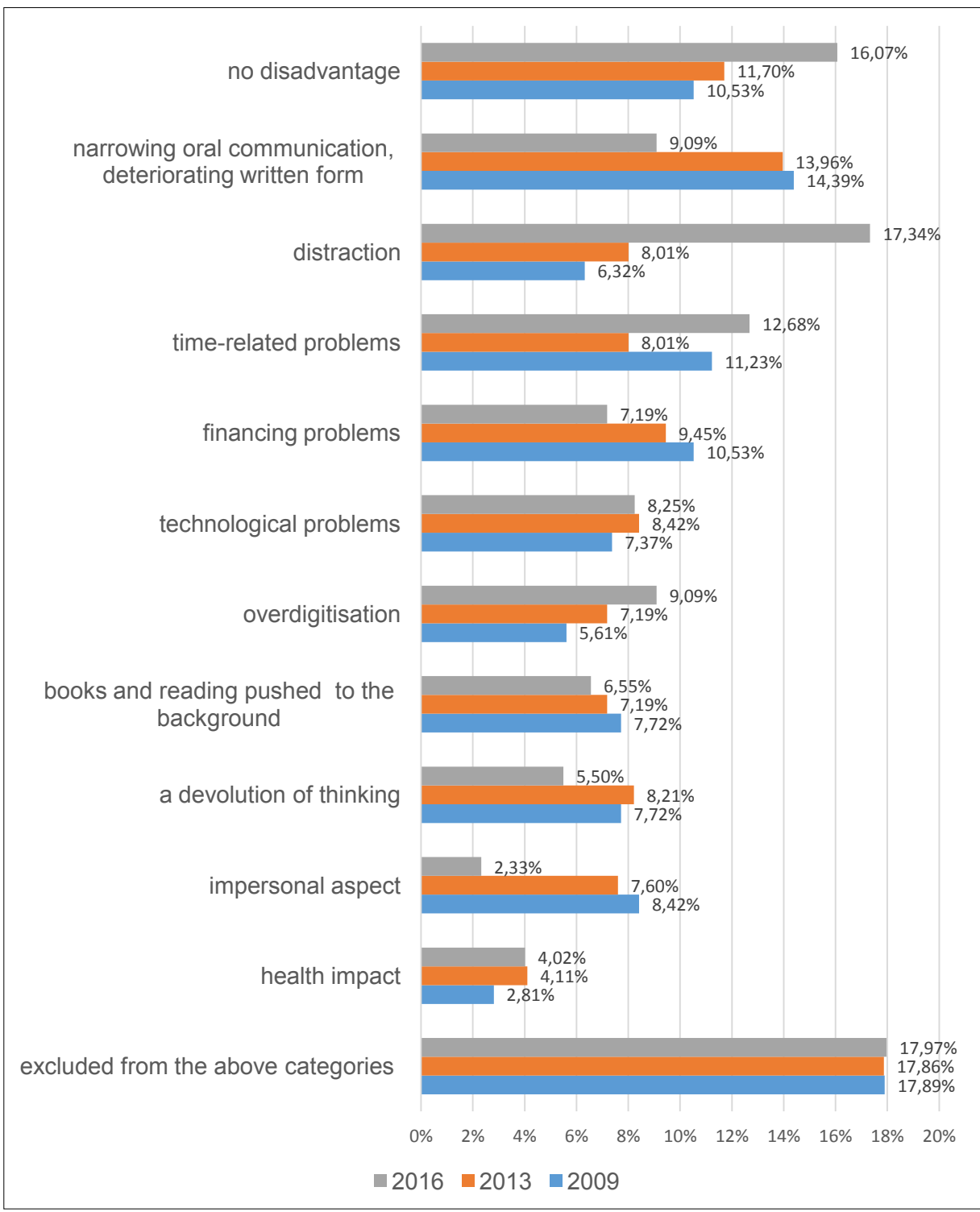

Fig. 3. The disadvantages of using ICT devices, according to teachers (the proportion of responses given in the category). 
The views on barriers to the use of ICT in education exhibit a change in emphasis: with time more and more teachers have learnt not to regard the new technological devices and solutions as their 'enemies'. (This is indirectly shown by the increasing number of respondents.) The change is indicated, on the one hand, by the fact that according to an increasing proportion of teachers, the use of digital devices in schools has no disadvantages whatsoever (even though the proportion of people who specify some condition is also on the rise). On the other hand, fewer people think that the use of these solutions narrows down communication or makes relationships impersonal, devolves thinking, throws children off reading, deteriorates the written form. During the seven years of the study there was also a fall in the proportion of respondents according to whom the use of the new technologies in schools makes students think less and read less, deteriorates writing; moreover, there are fewer financing problems. At the same time a greater proportion of teachers than in 2006 fear that the process of education is becoming overdigitised. There is an increase in the proportion of people that think that digital technologies have a deleterious effect on time management. When carrying out a deeper analysis of responses, we also found that the problem is not primarily the use of the technology itself but in many cases it is rather supplying the conditions of use that is too time-consuming. The most outstanding change during the period under survey, however, is connected to the students: in the three surveys the proportion of teachers who named students' distraction to be a disadvantage of using ICT (one of them) increased from $6 \%$ to $17 \%$. Due to the change, in 2009 this factor was significantly highlighted among the disadvantages pointed out by the respondents.

\section{How Progress Could be Made, According to Teachers}

Eliminating the mapped disadvantages may significantly promote the use of ICT in schools, but beyond this at the time of the 2013 and 2016 surveys we already attempted to explore possible solutions. We posed the most competent parties, the teachers, the question 'what would you need to use IT devices in the lesson (more)?'

The open question was responded to by 563 people, of whom $55(9.8 \%)$ would not change anything and are completely satisfied with their use of ICT and its frequency. They either believed their work to be 'fully digitised' - 'I use ICT in every lesson already, as I hold 99\% of my lessons with the help of an interactive board' - or making a conscious decision set a limit to the use of ICT: 'I wouldn't want to use it more than this. You can't solve everything with a computer, sometimes traditional methods are better.' These decisions are more often than not determined by the students' ages, too: 'I do not wish to use it more. I feel that the children in the age group I teach (grade 1) need more manipulation and play to gain experience.'

The overwhelming majority of respondents (with significant replies), $60.1 \%$ of the teachers, basically find it most important to develop the technological conditions in order to proceed. The magnitude and direction of the development are, however, viewed very differently by the teachers. The responses may be put in three subgroups, which reflect the given institutions' access to digital equipment. Many people deem it important 
to create a basic infrastructure, and the replies show that the institution of the respondents has insufficient equipment: 'If all rooms in our school were equipped with ICT devices and not only 4 computers were found in the staff room.' 'A turn-key system in all classrooms. (Instead of the circuitous method of borrowing it, moving it, resetting it.)' The other subgroup wishes for the uninterrupted operation and development of devices. They already have access to the devices, but their condition and standard is not adequate: 'A new bulb for the projector.' 'Better computers in the rooms for the students. A higher bandwidth wifi also in the rooms. 'Finally, respondents in the third subgroup wish not for the general availability of basic digital devices, as the institution has those, but would like to see newer devices to move forward: "Audience response/voting systems or tablets for the students. ' 'Smart phones with internet access for all students.'

To create the appropriate technological environment some teachers wish to nave not only the equipment, but find necessary some kind of support personnel, too. They wish to see 'an appropriate professional helping them set the technology before the lessons. So that everything can be spot-on and punctual and the different devices can be compatible.'

Another group of respondents reported a lack of some kind of software, which can be divided into three subgroups, too. Of the 159 people (28.2\%) reporting this, 59 wish for a positive change through the purchase of digital contents and computer software: 'Support material in great quantities, for instance digital teaching materials to go with all students' books, the kind you may find at Mozaik publishing house, as well as the development of these, and easily utilisable exercises and tests.' 'Some teaching programmes that are related to the subjects taught be my.'

The other group of software facilitating the (more active) use of ICT in lessons is the teachers' knowledge, their 'user software'. 67 people reported the need: 'Primarily the further development of my own proficiency.' 'I am wary of difficulties and stumbling blocks, I am a little cautious in this field, of which I think I have insufficient knowledge and skills. Despite my relative youth I am not knowledgeable and open enough. I need new motivation.'

Since the respondents are teachers, the solution seems obvious: a well-chosen teacher further training programme might be an excellent field of gaining new motivation and developing the necessary skills (the third subgroup of 'software' deemed necessary). In spite of this, only 33 people (approximately half of the people that themselves indicated the need for developing their own skills) articulated this demand: 'Available trainings that help veteran teachers to learn how to make exercises and use the solutions step by step.' 'Efficient trainings. I have just come from such a training course, and it was very productive. It raised my attention to the use of the interactive board. Since then I have been trying to use it.'

The third group of responses disclosing the elements necessary for a change $(21.7 \%)$ is related to time. A substantial number of our respondents wish for more free time to be able to prepare their teaching materials so that more ICT solutions may appear in the lessons. There are many who would spend such time on their own development: 'More free time, so that I can learn more and find more on the teaching material.' Several people wish to get more time in the school: 'Longer breaks between the lessons so that I can get 


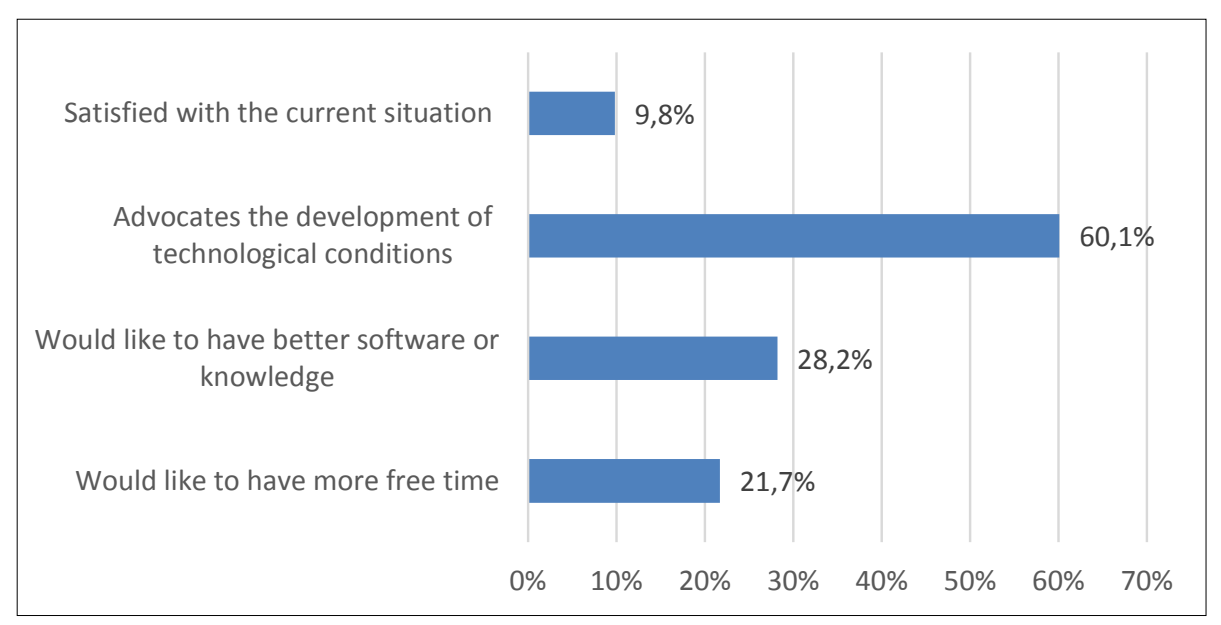

Fig. 4. What is needed for progress, according to teachers.

from one place to the other and have time to prepare the devices as well as "switch over" my mind from one subject to another or one year to another.' Moreover, some people deem possible the solution where the lessons are longer, because they think 'more time is needed for teaching the materials in a varied way.'

On the basis of the responses we can draw the conclusion that Debrecen teachers' use of ICT is primarily hindered by first-order barriers (Ertmer 1999, Pine-Thomas 2017), in other words, external barriers (Tedla 2012, Johnson et al. 2016). This finding in itself is not surprising, as the factor also appeared in the conclusions to earlier surveys. What is indeed unexpected is the significantly high number of replies like that, as two respondents of three would mainly improve this. It is sad to see that a value from the late ' 90 s is nearly identical to the findings of the SITES surveys (Pelgrum 2001). The result is that the impact of different central budgetary programmes targeting assets purchasing and technological development is questionable, and there is a long way to go here. Until there is some improvement, however, no significant advancement can be expected in the educational use of ICT.

\section{Conclusion}

There is a general lack of satisfaction with today's education. Some criticise the available devices, others think teachers are not prepared enough, but a good many people encourage the reshaping of the teaching environment, too. In accordance with this, the areas of development are imagined differently, but all parties agree that digital technology will play an important role in this process. As Warlick puts it, 'We need technology in every classroom and in every student and teacher's hand, because it is the pen and paper of our time, and it is the lens through which we experience much of our world' (Warlick, 2006 , 1). In most countries educational policy strives to facilitate the use of digital technologies in the lessons by both teachers and students, but full-scale access is only pos- 
sible in some institutions. Yet, despite the centralised decision to improve, changing the process of teaching and learning is not without problems in most places (Wastiau et al., 2013, Rončević et al., 2017), and the impact of ICT is not as widespread in education as in other walks of life. This is owing to the fact that integrating ICT in teaching and learning is a complex process, which may be hindered by different barriers.

The three subsequent surveys conducted in the second largest city of Hungary had the goal of disclosing barriers. We wished to learn about the disadvantages of the use of ICT in schools as teachers saw them, and what they needed to effect improvement and yield a more frequent and efficient use. Our findings show that fewer and fewer teachers regard the new solutions as their 'enemies', the proportion of people who think the use of ICT has no disadvantages whatsoever grew from $11 \%$ to $16 \%$. Moreover, most of them require more and/or better devices and digital contents in their classrooms. $60 \%$ of the respondent teachers think that some technological development is important for progress. There is, however, a great difference between the types and quantities of desired tools, as there is an immense disparity between the states of technological equipment of various schools. A significant goal should be decreasing this disparity and creating a similarly high supply. Taking into consideration the relatively fast amortisation rate of technological devices and the ever developing and expanding field of technology, however, this solution demands a remarkably high expenditure from the budget. Multiple of the current support would be needed for even laying the foundations, and then for continuous maintenance and development. A solution to the problem would be institutions' introducing the BYOD (Bring Your Own Device) model, that is, allow students to use their own devices for educational purposes. According to our respondents, however, this would not be a solution everywhere: 'the general use of mobiles and tablets is impossible, as some of the students do not have the necessary devices and internet access, while school wi-fi networks cannot satisfy their demands.

Besides the lacking devices Debrecen's teachers are most hindered in using the new technologies by associating the deterioration of students' attention with digital technology. The $6 \%$ of respondents with this view measured in 2009 rose to $17 \%$ in 2016 . This perspective or experience influences their attitudes and, in addition to an increased sense of overwork, creates a kind of cognitive barrier to the use of ICT. Even if decision-makers resolve to invest in the technology along the lines of the 'build it and they will come' principle (Scheuermann and Pedró, 2009), hoping that sooner or later schools and teachers will accept and utilise those, it would be at least as important to provide appropriate training and continuous further training for teachers. The demand is reinforced by the finding that few teachers integrate ICT effectively even where the infrastructure is available (Becta, 2004), and the use of new devices is not readily concomitant with a methodological renewal. For instance, many teachers view the interactive board as an electronic version of the conventional blackboard and many use it in that way (Armstrong et al., 2005), while several other possibilities remain unexploited. Moreover, there are a lot of teachers who do not apply the board in a functional way but merely use it as a simple screen to project upon. This type of attitude should be changed first, because new learning environments, new technologies demand new methods and views on the part of teachers (Lavonen et al., 2015). 
All of these presuppose that in order to use digital technologies in schools there is the need for a positive attitude, sufficient hardware and software, support, time, trainings, and none of these components can do the job on their own, more are needed to perform teaching that meets the demands of the age. The presence of all these components, however, greatly intensifies the probability of integrating ICT in school work efficiently. At the same time, all competent parties must acknowledge that the appropriate use of ICT assists work, but using it in an unfavourable way can hinder the processes of teaching and learning.

\section{References}

Al-Shboul, M.A. (2019). Incentives and Obstacles Influencing Faculty Members' Use of Information and Communication Technology (ICT). Modern Applied Science, 13(3), 66-100.

Alshmrany, S. and Wilkinson, B. (2017). Factors Influencing the Adoption of ICT by Teachers in Primary Schools in Saudi Arabia. International Journal of Advanced Computer Science and Applications, 8(12), $143-156$.

Armstrong, V., Barnes, S., Sutherland, R., Curran, S., Mills, S., and Thompson, I. (2005). Collaborative research methodology for investigating teaching and learning: The use of interactive whiteboard. Educational Review, 57(4), 457-469.

Baggott L.L., McFarlane, A. and Brawn, R. (2003). Knowledge transformation through ICT in science education: A case study in teacher-driven curriculum development - Case-Study 1. British Journal of Educational Technology, 34(2), 183-199.

Balanskat, A., Blamire, R., Kefala, S. (2006). The ICT impact report. A review of studies of ICT impact on schools in Europe. European Schoolnet, Brussels.

Bandyopadhyay, A. (2013). Technology Integration Before Sstudent Outcomes: Factors Affecting Teacher Adoption of Technology in India. Doctoral dissertation. University of Maryland, College Park.

Becta (2004). A Review of the Research Literature on Barriers to the Uptake of ICT by Teachers. Becta. https://dera.ioe.ac.uk/1603/1/becta_2004_barrierstouptake_litrev.pdf

Bingimlas, K. (2009). Barriers to the Successful Integration of ICT in Teaching and Learning Environments: A Review of the Literature. Eurasia Journal of Mathematics, Science and Technology Education, 5(3), 235-245.

Cox, M., Preston, C. and Cox, K. (1999). What Motivates Teachers to Use ICT? British Educational Research Association Annual Conference. Brighton. from: http://www.leeds.ac.uk/educol/ documents/00001329.htm [Accessed: 23.06.2019]

Ertmer, P.A. (1999). Addressing first- and second-order barriers to change: Strategies for technology integration. Educational Technology Research and Development, 47(4), 47-61.

European Commission (2013). Survey of Schools: ICT in Education. Benchmarking Access, Use and Attitudes to Technology in Europe's Schools. European Commission Luxembourg. from: http: //ec . europa.eu/ information_society/newsroom/cf/dae/document.cfm?doc_id=1800 [Accessed: 14.08.2019]

European Commission (2019). 2nd Survey of Schools: ICT in Education. Benchmark progress in ICT in schools. European Commission, Luxembourg. from: https://ec.europa.eu/digital-single-market/en/news/2nd-survey-schools-ict-education [Accessed: 14.08.2019]

Fazekas, Á. (2016): A közoktatás-fejlesztési beavatkozások hatásmechanizmusai - jelentés az empirikus adatfelvételröl. Kézirat. http://www.impala.elte.hu/wp-content/uploads/2013/05/101579-e. jelent\%C3\%A9s-2016-01.pdf [Accessed: 11.09.2019]

Hadley, M. and Sheingold, K. (1993). Commonalities and Distinctive Patterns in Teachers Integration of Computers. American Journal of Education, 101, 261-315.

Hennessy, S., Ruthven, K. and Brindley, S. (2005). Teacher perspectives on integrating ICT into subject teaching: Commitment, constraints, caution and change. Journal of Curriculum Studies. 37(2), 155-192

Hew, K. and Brush, T. (2007). Integrating technology into K-12 teaching and learning: current knowledge gaps and recommendations for future research. Educational Technology Research and Development, 55(3), $223-252$. 
Hruskocy, C., Cennamo, K.S., Ertmer, P.A. and Johnson, T. (2000). Creating a Community of Technology Users: students become technology experts for teachers and peers. Journal of Technology and Teacher Education, 8(1), 69-84.

Johnson, A. M., Jacovina, M. E., Russell, D. E. and Soto, C. M. (2016). Challenges and solutions when using technologies in the classroom. In: Crossley, S. A. and McNamara, D. S. (Eds.), Adaptive educational technologies for literacy instruction. Taylor \& Francis, New York, 13-29.

Kafyulilo, A., Fisser, P. and Voogt, J. (2016). Factors Affecting Teachers' Continuation of Technology Use in Teaching. Education and Information Technologies, 21(6), 1535-1554.

KIRSTAT Oktatási Hivatal Köznevelési Nyilvántartási Főosztály, Budapest. https://dari.oktatas .hu/ index .php?id=kozerdeku [Accessed: 07.08.2019]

KSH (2017): Köznevelési adatok, 2016/2017 (elözetes adatok) https : //www . ksh . hu/docs/hun/xstadat/ xstadat_eves/i_zoi010b.html [Accessed: 09.09.2019]

Lavonen, J., Korhonen, T. and Juuti, K. (2015). Finnish teachers' professionalism is built in teacher education and supported by school site. Hungarian Educational Research Journal, 5(3), 19-30.

Law, N., Lee, M., Chan, A. and Yuen, A. (2008a). Factors Influencing the Impact of ICT use on Students' Learning. Proceedings of the 8th International Rangeland Congress, 2008, 1-17. from: https://www . iea.nl/sites/default/files/2019-04/IRC2008_Law_Lee_etal.pdf [Accessed: 07.08.2018]

Law, N., Pelgrum, W.J. and Plomp, T. (2008b). Pedagogy and ICT use in schools around the world: findings from the IEA SITES 2006 study. Springer, Hong Kong.

Mumtaz, S. (2000). Factors affecting teachers' use of information and communications technology: a review of the literature, Journal of Information Technology for Teacher Education, 9(3), 319-342.

Orlando, J. (2014). Teachers' changing practices with information and communication technologies: an up-close, longitudinal analysis. Research in learning technology, 22(1), 21354. doi: http://dx.doi. org/10.3402/rlt.v22.21354 Publisher Full Text

Pelgrum, W.J. (2001). Obstacles to the Integration of ICT in Education: Result from Worldwide Educational Assessment. Computers \& Education, 37(2), 163-178.

Pine-Thomas, J.A. (2017). Educator's Technology Integration Barriers and Student Technology Preparedness as 21st Century Professionals. Doctoral dissertation. Walden University, Minneapolis.

Player-Koro, C. (2012). Factors Influencing Teachers' Use of ICT in Education. Education Inquiry, 3(1), 93-10.

Pusztai, G. (2015): Az eredményesség kapcsolati beágyazottsági háttere. In: Imre Anna (Ed.): Eredményesség és társadalmi beágyazottság. Oktatáskutató és Fejlesztő Intézet, Budapest. pp. 23-36.

Rončević, B.Z., Pahljina-Reinić, R., Kolić-Vehovec, S. (2017). Predictors of ICT Use in Teaching in Different Educational Domains. European Journal of Social Sciences Education and Research, 11(2), $145-154$. from: http://journals.euser.org/files/articles/ejser_sep_dec_17_nr_2/Barbara.pdf [Accessed: 08.09.2019]

Rosen, L.D. and Weil M.M. (1995). Computer availability, computer experience and technophobia among public School teachers. Computers in Human Behaviour, 11(1), 9-31.

Scheuermann, F. and Pedró, F. (Eds.) (2009). Assessing the Effects of ICT in Education Indicators, Criteria and Benchmarks for International Comparisons: Indicators, Criteria and Benchmarks for International Comparisons. OECD, Joint Research Centre - European Commission. Luxembourg.

Szemerszki, M. (Ed.) (2016): Hátrányos helyzet és iskolai eredményesség: Az általános iskolák hátránykompenzáló lehetőségei. Oktatáskutató és Fejlesztő Intézet), Budapest.

Tay, L.Y., Nair, S.S. and Lim, C.P. (2018). Old Wine in New Bottle? How Technologies Are Being Used in an Elementary School in Singapore. In: Ellis, R.A. and Goodyear, P. (Eds.), Spaces of Teaching and Learning. Understanding Teaching-Learning Practice. Springer, Singapore. 173-194.

Tedla, B.A. (2012). Understanding the Importance, Impacts and Barriers of ICT on Teaching and Learning in East African Countries. International Journal for e-Learning Security, 2(3/4), 199-207.

Varga, J. (Ed.) (2015): A közoktatás indikátorrendszere. Magyar Tudományos Akadémia Közgazdaság-Tudományi Intézet, Budapest.

Warlick, D (2006): Curriculum is Dead. http: //2cents . onlearning . us/?p=420 [Accessed: 07.09.2019]

Wastiau, P., Blamire, R., Kearney, C., Quittre, V., Van de Gaer, E., Monseur, C. (2013). The use of ICT in education: A survey of schools in Europe. European Journal of Education, 48(1), 11-27.

Winnans, C. and Brown, D.S. (1992). Some Factors Affecting Elementary Teachers' Use of the Computer. Computers in Education, 18. 301-309.

Zhao, Y., Pugh, K., Sheldon, S. and Byers, Y.L. (2002). Conditions for Classroom Technology Innovations. Teachers Cotlege Record, 104(3), 482-515. 
A. Buda, MSc in Maths - Descriptive Geometry - Information Technology, Dr. habil. in Pedagogy. Currently he is lecturer at the IInstitute of Educational Studies and Cultural Management, University of Debrecen, and has previously taught in different secondary schools and the Institute of Maths and Descriptive Geometry. Within Pedagogy, his professional field is Didactics, including a special research interest in E-learning and the use of information and communication technologies in education. He is involved in several projects as researcher and project director. 
